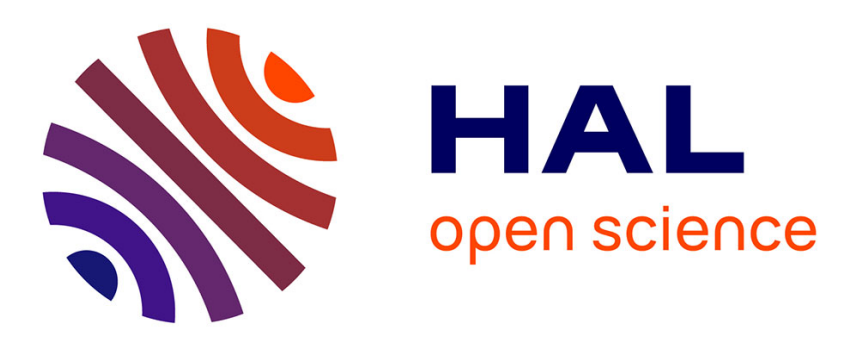

\title{
Mechanical studies of the multi-gap spoke cavity for European project HIPPI
}

\author{
H. Gassot, S. Blivet, T. Junquera, G. Olry, E. Zaplatine
}

\section{To cite this version:}

H. Gassot, S. Blivet, T. Junquera, G. Olry, E. Zaplatine. Mechanical studies of the multi-gap spoke cavity for European project HIPPI. 12th International Workshop on RF Superconductivity, Jul 2005, Ithaca, United States. pp.190-192, 10.1016/j.physc.2006.03.138 . in2p3-00105521

\section{HAL Id: in2p3-00105521 https://hal.in2p3.fr/in2p3-00105521}

Submitted on 11 Oct 2006

HAL is a multi-disciplinary open access archive for the deposit and dissemination of scientific research documents, whether they are published or not. The documents may come from teaching and research institutions in France or abroad, or from public or private research centers.
L'archive ouverte pluridisciplinaire HAL, est destinée au dépôt et à la diffusion de documents scientifiques de niveau recherche, publiés ou non, émanant des établissements d'enseignement et de recherche français ou étrangers, des laboratoires publics ou privés. 


\title{
MECHANICAL STUDIES OF THE MULTI-GAP SPOKE CAVITY FOR EUROPEAN PROJECT HIPPI
}

\author{
H. GASSOT*, S. BLIVET, T. JUNQUERA, G. OLRY, Institut de Physique Nucléaire d'Orsay, France \\ E. ZAPLATIN, FZ Jülich, Germany
}

\section{Abstract}

Within the HIPPI (High Intensity Pulsed Proton Injector) project, supported by the 6th PCRD (framework programme for research and development) of the European Union, the German research centre Forschungszentrum Jülich proposed a multi-spoke $\mathrm{H}$-cavity for the intermediate energy section $(\beta=0.5)$ of high power proton linear accelerators. The IPN Orsay is associated with FZ Jülich for the prototype design, and before that, all preliminary mechanical studies.

A triple-spoke superconducting cavity has a more complicated geometry, compared to the same beta elliptical cavity. As a consequence the design requires some sophisticated tools, like the CAD (Computer Aided Design) code CATIA. In addition, in order to solve the specific mechanical problems imposed by external constraints, a sophisticated mechanical simulation tool CAST3M (Calcul et Analyse de Structure et Thermique par la méthode des Eléments Finis) is used [1]. But no commercial modeling/FEA exchange software exists between CATIA and CAST3M, so the first investigation consisted in the development of a dedicated programme for this purpose.

The mechanical behaviour of the triple spoke cavity in static and dynamic regime was studied with these codes. The results are presented and discussed in this report.

Keywords: spoke superconducting cavity; design; modeling/FEA; mechanical simulations

\section{CAVITY DESIGN}

The design is optimized at first by the electromagnetic studies (FZ Jülich), in order to reach the highest accelerating efficiency [2]. The triple-spoke is made of niobium and defined as a multi-gap H-cavity. In the cylindrical outer conductor are picked three spoke tubes, which are rotated by 90 degrees from one to the next. The end cell contains a conical part, to minimize the magnetic field on the spoke surface. The optimized parameters are given in table 1.

The multi-spoke superconducting cavity having a complicated geometry, the drawing is realized with the $\mathrm{CAD}$ code CATIA V5, figure 1.

\section{CATIA-CAST3M INTERFACE}

In anticipation of further multi-disciplinary investigations, the CAST3M code was chosen to perform the FEM calculations. Its open design enables user-added extensions

\footnotetext{
*gassot@ipno.in $2 \mathrm{p} 3 . \mathrm{fr}$
}

Table 1: Some parameters

\begin{tabular}{|l|c|c|}
\hline Parameter & Values & Unity \\
\hline Frequency & 352 & $\mathrm{MHz}$ \\
\hline$\beta=v / c$ & 0.48 & \\
\hline $\mathrm{R}$ aperture & 2.5 & $\mathrm{~cm}$ \\
\hline$\beta \lambda / 2$ & 20.44 & $\mathrm{~cm}$ \\
\hline$R_{c a v}$ & 21.7 & $\mathrm{~cm}$ \\
\hline cavity length & 78 & $\mathrm{~cm}$ \\
\hline $\mathrm{G}$ & 93 & $\Omega$ \\
\hline$E_{p k} / E_{a c c}$ & 3.95 & \\
\hline$B_{p k} / E_{a c c}$ & 8.93 & $\mathrm{mT} / \mathrm{MV} / \mathrm{m}$ \\
\hline
\end{tabular}

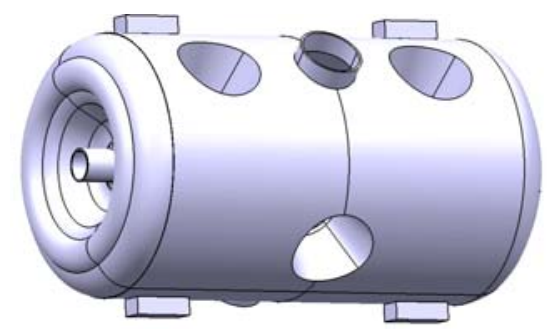

Figure 1: CAD design of the multi-spoke cavity

to integrate peculiar equations and conditions outside the usual frame of mechanical calculations.

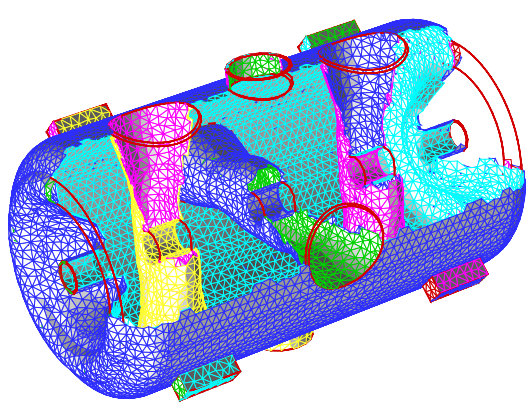

Figure 2: FE meshing with some geometrical baselines

Many CAD-FEA exportation tools work at the level of model description, often needing manual intervention to correct the exported geometry and recreate the meshing after model improvements. All these operations are very time-consuming with complex geometries. In addition to CAD, the CATIA V5 code offers some possibilities to do a preliminary finite element analysis, and the meshing, conformable to the CAD model, can be exported in an ex- 
changeable format. A program, developed to translate this meshing into a format usable by CAST3M, was further extended with geometrical analysis and sorting of all coherent subdomains to provide "ready to calculate" data to the FEA code. The meshing of the triple Spoke cavity is shown in figure 2. The main interests of mesh level exchanges are the time-savings which enable quick feedback for CAD and the use of a common reliable meshing by the calculation codes, facilitating data transfers without interpolation smoothing.

\section{STATIC ANALYSIS}

The cavity deformation under vacuum conditions has been simulated. The meshing is composed of 21719 nodes and 66243 elements. Two possible means of fixation have been studied for the cavity, the former consists in fixing the beam pipes, and the latter in fixing four supports (figure 1) directly to the cryostat. It seems, after simulations, that the optimal wall thickness is $4 \mathrm{~mm}$. But for manufacturing reasons, the end cup wall is thinner. The use of torus shaped stiffeners can reduce the stress peak and also increase the cavity's stability. The stress distribution with the four supports fixation type is presented in figure 3. The stress peak is about $15 \mathrm{MPa}$, largely lower than the elastic limit of the niobium (near $50 \mathrm{MPa}$ at room temperature).

\section{CAST3M calculation}

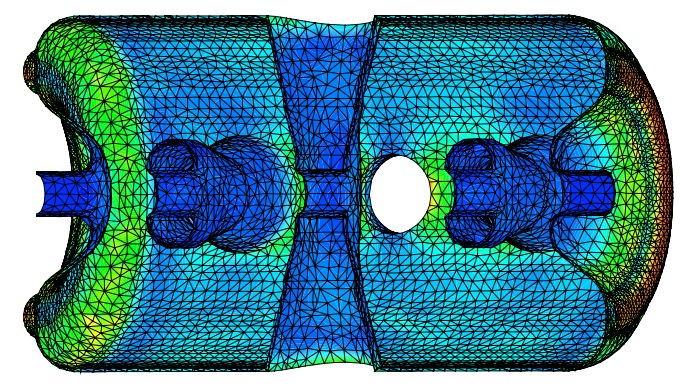

Figure 3: Von Mises stress distribution

The results obtained both by CAST $3 \mathrm{M}$ and by CATIA are compared in table 2 . The thinckness of the end-cup is 3 $\mathrm{mm}$, the torus thinckness is $4 \mathrm{~mm}$, and the thinckness of the cylindrical part of the cavity is $4 \mathrm{~mm}$.

Table 2: 1 bar external pressure simulation

\begin{tabular}{|l|c|c|}
\hline code & CAST3M & CATIA \\
\hline max displacement & $0.072 \mathrm{~mm}$ & $0.070 \mathrm{~mm}$ \\
\hline max stress & $15.3 \mathrm{MPa}$ & $14.8 \mathrm{MPa}$ \\
\hline
\end{tabular}

\section{DYNAMIC BEHAVIOURS}

In pulsed regime, the cavity has its own mechanical eigenmodes which could be excited by the external noise or inner mechanical forces. With the torus stiffeners, the frequency of the first eigenmodes has been considerably raised, to avoid the excitation from environment noise. Some calculated eigenmodes are presented in the table 3. FZ Jülich has performed the simulations with a commercial code ANSYS. A good agreement could be observed. The deformation of the first mode is illustrated in figure 4 .

Table 3: Eigenmodes

\begin{tabular}{|l|c|c|c|}
\hline code & $\begin{array}{c}\text { CAST3M } \\
\text { w/o stiffener }\end{array}$ & $\begin{array}{c}\text { CAST3M } \\
\text { stiffener }\end{array}$ & $\begin{array}{c}\text { ANSYS } \\
\text { stiffener }\end{array}$ \\
\hline eigenmode 1 & $83 \mathrm{~Hz}$ & $138 \mathrm{~Hz}$ & $150 \mathrm{~Hz}$ \\
\hline eigenmode 2 & $219 \mathrm{~Hz}$ & $259 \mathrm{~Hz}$ & $275 \mathrm{~Hz}$ \\
\hline eigenmode 3 & $241 \mathrm{~Hz}$ & $379 \mathrm{~Hz}$ & $392 \mathrm{~Hz}$ \\
\hline eigenmode 4 & $243 \mathrm{~Hz}$ & $403 \mathrm{~Hz}$ & $406 \mathrm{~Hz}$ \\
\hline eigenmode 5 & $308 \mathrm{~Hz}$ & $436 \mathrm{~Hz}$ & $439 \mathrm{~Hz}$ \\
\hline eigenmode 6 & $311 \mathrm{~Hz}$ & $460 \mathrm{~Hz}$ & $469 \mathrm{~Hz}$ \\
\hline
\end{tabular}

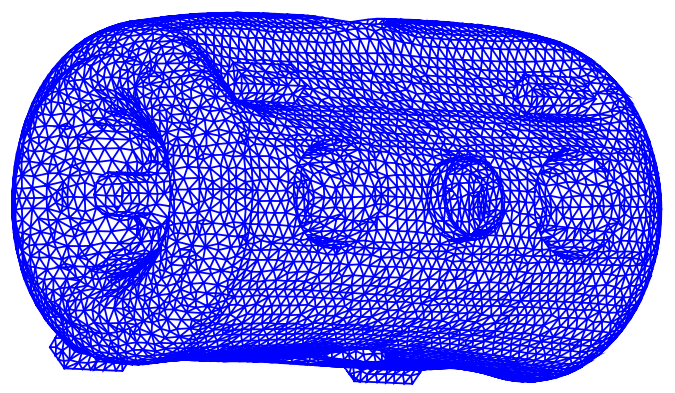

Figure 4: vibration mode 1, deformation

\section{CONCLUSIONS AND PERSPECTIVES}

Mechanical studies for HIPPI multi-gap cavities have been successfully started at IPN Orsay in collaboration with FZ Jülich. The behaviour of the geometry and the stiffeners has been studied and assessed to be in the working range.

Some other multi-disciplinary simulations are planned, especially the frequency shift of the cavity due to mechanical deformations. For this, the electromagnetic code SoPRANO will be used and interfaced the same way with CATIA and with CAST3M, to facilitate data exchange between electromagnetic and mechanical analysis. Thus, the coupling between mechanical and electromagnetic calculations could be realized with more precision. Finally, the delay of the studies should be considerably reduced.

\section{REFERENCES}

[1] H. Gassot, proceedings of the 8th European Particle Accelerator Conference, June 2002, Paris

[2] E. Zaplatin et al, Proceedings of EPAC 2004, Lucerne, Switzerland. 